\title{
TRADEMARK LICENSING AND VERTICAL RESTRATNTS IN FRANCHISING ARRANGEMENTS
}

\author{
J AMES M. TREBCE $\dagger$
}

Franchising, a method of distribution increasingly utilized by businesses and scrutinized by agencies of government, provides corporations with control over access to distribution channels and control over the business practices of franchisees-dealers and distributorsin those channels. ${ }^{1}$ The franchisor can control access of distributors to a distribution channel by selectively choosing outlets for its products; it can control access of manufacturers to a distribution channel by controlling, through contract or coercion, the nature of the inventory of its franchisees. The franchisor can also force its will upon franchisees in such matters as pricing, advertising, merchandising, selling and hiring. It can, in short, restrict the freedom of structurally independent economic units to make decisions concerning basic business problems.

Franchising relationships generally raise problems of both antitrust and trademark policy. Some franchising relationships fit the model for vertical restraints of trade as, for example, when the franchisor dictates the pricing policies of the franchisee. This form of restraint is thought to be as harmful to competition as a horizontal price fixing agreement between competing manufacturers or distributors. On the other hand, many franchising agreements are parts of a wide system for the distribution of goods and services under a single trademark. Consumers expect to find identical services, products and prices whenever they see the trade symbol-a result which can only be attained by control of the franchisees from above. The suggestion is sometimes made that the legal limits of franchisee control

$\uparrow$ B.S. 1959, M.A. 1962, LL.B. 1961, University of Illinois. Associate Professor of Law, University of Texas. Member, Illinois Bar.

I In the past several years, the Supreme Court of the United States has decided cases challenging the legality of attempts by Sealy Corporation and the White Motor Company to control by contract the marketing area of franchised dealers, United States v. Sealy, Inc., 388 U.S. 350 (1967); White Motor Co. v. United States, 372 U.S. 253 (1963); by General Motors to control by contract the location of its franchised dealers' places of business, United States v. General Motors Corp., 384 U.S. 127 (1966); and by the Atlantic Refining Company to control by coercion the sources of tires, batteries and accessories carried by its retail service station dealers. Atlantic Refining Co. v. FTC, 381 U.S. 357 (1965). 
should be determined, not merely by antitrust policy, but by trademark policy as well. This suggestion implies the existence of a general principle which would restrain action otherwise dictated by antitrust considerations in deference to trademark policy.

This article is concerned exclusively with trademark considerations. Its goal is to explore the rationale for permitting the use of trademarks in a competitive economy, for encouraging the transfer of trademarks and for countenancing their licensing or franchising. The article will attempt to lay a foundation for assessing the validity of the proposition that, in some situations, action dictated by antitrust principles must be stayed due to considerations of trademark policy. The antitrust solutions to the problem of vertical restraints in franchising are left for other commentators.

\section{II}

Consider the many decisions confronting a consumer with a limited amount of money to spend. He must choose between recreation and investment, weigh education against creature comforts and balance security against adventure. ${ }^{2}$ If he allocates money for recreation, he must choose between the present and the future, between Miami and Europe, between the theatre and the cabaret. In buying food he must spend for milk or wine, bread or cake, fish or fowl. If he buys razor blades, he must choose between stainless and plain, foreign and domestic, patented and unpatented, plastic-coated and oil-filmed, advertised and un-advertised, double-edged and single-edged, dispenserpacked and paper-wrapped, high-priced and low-priced.

The consumer's task is to allocate dollars among thousands of transaction opportunities so that his satisfactions are maximized. But a consumer never can consider more than a small number of possibilities and, at the time of purchase, never really can know very much about the satisfaction he will get from a particular can of tomatoes, for example, since he cannot open the can in the supermarket aisle.

Perhaps the consumer's best course of action is to develop strategies to reduce the number of choices ${ }^{3}$ and then to make selections

2 "The man who buys a pint of whiskey today does not know to what degree he prejudices his son's college education 20 years hence." Bater, Consumer Behavior as Risk Taking, in Proceedings, 43Rd National Conference of the AMERICAN MARKETING Association 389-90 ( $R$. Hancock ed. 1960) [hereinafter cited as Bauer].

${ }^{3}$ In a supermarket shopping test, selected consumers were asked to make purchases in twenty different categories of products and were instructed to select the package in each category which offered the greatest quantity for the money. Each consumer was given plenty of time to make selections, but was not permitted to use paper, pencil or calculating device. The results suggest that the typical supermarket shopper spends about nine per cent more than a hypothetical consumer who always selects the most economical package. Friedman, Constmer Confusion In the Selection of Supermarket Products, 50 J. AppLIEd PsyChOLOGY 529 (1966). The failure of 
from the narrowed field by relying on past experience and present expectations. Thus he initially might narrow his choice by focusing only on items carrying familiar trademarks or trade names. He then might make his final selection on the supposition that a particular product will be acceptable because it is produced or distributed by a firm which has produced acceptable products in the past. ${ }^{4}$

In order to use expectations profitably in making purchasing decisions, the consumer must be provided with a symbol which will signal that a particular product is connected with a particular reputation. $\mathrm{He}$ also must have some assurance that the trade symbol will continue to represent the same production and distribution system which has been either satisfactory or unsatisfactory in the past. This assurance has been provided by giving firms a right to the exclusive use of their trade symbols. Presumably the concern of firms for the continuing patronage of their customers will provide the incentive to maintain standards of quality for goods sold under a particular trademark.

Consumers, as well as businesses, are concerned with brand loyalty. Consumers have an important interest in the general practice of returning to the place or product that previously served them well, as a means of striking a balance between the need to conserve time and energy in the market place and the goal of making a sensible allocation of financial resources. ${ }^{5}$ People might approach purchasing decisions without relation to past experiences, by testing the merits of each item or by concentrating on price alone and assuming that quality differentials will not be extensive. Nevertheless, the number of choices, the limits of time and the difficulties involved in weighing quality at the point of purchase make both reasonable and useful a system which provides consumers with a means of associating presently-tendered products with past experiences. ${ }^{6}$

In such a system, a firm's trademark can be put to different uses by different consumers, and the same consumer can make

the consumers tested by Friedman to make the best selections within the twenty categories specified emphasizes the difficulties consumers generally face in making purchasing decisions involving hundreds of outlets, thousands of categories and many variables in addition to price and quantity.

4 Bauer reports that one of his associates interviewed a woman consumer who expressed a preference for small shops because she thought that the proprietor of a small shop reduced the complexity of her purchasing decisions by reducing the number of brands confronting her and by (hopefully) weeding out the least preferable. Bauer 396-97.

5 Although consumers do develop buying habits based on trademarks or "brands," the likelihood that past purchasing patterns will be repeated seldom approaches certainty. Any particular choice appears to be related to the last choice, the last several choices and the elapsed time since the last choice. Kuehn, Consimer Brand Choice as a Learming Process, J. AdvERTISING Researce, Dec. 1962, at 10. See also Frank, Brand Awareness as a Probability Process, 35 J. Bus. 43 (1962); Kanungo \& Dutta, Brand Awareness as a Function of Its Meaningfulness, Sequential Position and Product Utility, 50 J. Applied Psychology 220 (1966).

- See Bauer 391. 
different uses of different marks. A mark can be used either to economize the effort of decision making or to reduce risks where the consumer's information is inadequate or the consequences of his action incalculable. ${ }^{7}$ Where the purchase decision involves a complex, highpriced, untried or possibly injurious product, the consumer is likely to make some use of the source symbol to reduce his risks. For example, an average person who wishes to purchase a diamond will surely prefer to deal with Tiffany's than with a stranger offering a "good buy" on some "interesting jewelry" in Central Park.

However, if the product is a common and simple household item such as sugar, it is unlikely that consumers will rely on a trademark as a means of reducing risks. Consumer loyalty to a brand of sugar, if it exists at all, will be a function of choice reduction rather than risk reduction.

Of course, consumers need not utilize marks at all in making purchases. Consumers can test some products themselves and can get information about particular products from many sources. For some very high-risk decisions, some consumers probably would be unwilling to rely consciously on a trademark to reduce risk, preferring to check and test themselves; in some low-risk situations, some consumers doubtless would be unwilling to rely consciously on a trademark to reduce choices, preferring instead to focus on price. In general, however, it can be expected that most consumers will make some use of trademarks in most purchasing situations to reduce choices, to reduce risks or for both purposes.

Consumers not only make various uses of marks, but also vary in the way they perceive "the source" of a product. It seems likely that sometimes trademarks will be associated with a general reputation for quality and sometimes with a specific production process assumed to have a particular relation to quality. "General quality" connotations might include: "this product bears the same mark as products of the

7 Product source is usually a very important factor in high risk decisions. See, e.g., Bauer, Risk Handling in Drug Adoption: The Role of Company Preference, 25 PUB. OPINION Q. 546 (1961). There is some evidence that professional buyers discount source in high risk situations more than others, including well-educated, technically informed consumers. See T. L evitr; INDUSTRIAL PuRCHAsing BEHavion: A Study of Communicatrons EFFrcts 90-91, 108-09 (1965). Starbuck \& Bass, Ant Experimental Study of Risk-Taking and the Value of Information in a New Product Context, $40 \mathrm{~J}$. BUS. 155 (1967), make the point that the availability of information significantly improves the quality of the manufacturer's decision to introduce a new product. It seems clear that the availability of information that a particular source has performed well in the past will improve the quality of the consumer's purchasing decision.

8 While the effect of source varies among purchasers and with the degree of risk involved, it quite clearly has a massive impact in the real world. People do tend to patronize sources they perceive as trustworthy. Levitt, sitpra note 7 , at $31,71-72$, $146,162$. 
same type which gave me satisfaction before;" "this product bears the same mark as products of a different type which gave me satisfaction before;" 10 this product bears a mark which I have seen advertised and about which I have heard nothing adverse;" "this product bears a mark long known to my family or friends as the mark of a firm with relatively stable and acceptable practices, policies, traditions, values and goals." 11 "Specific" quality connotations might include: "this product was made by $\mathrm{X}$ individual;" "this product came from a plant located at X place;" 12 "this product contains X ingredient;" or "this product was made according to $\mathrm{X}$ formula." 13

Of course, neither the specific quality nor the general quality list is exhaustive. A consumer might make no more use of a mark than to assume that, within each product line, all products presently confronting him bearing the same mark are uniform in quality. Or, on the other hand, he might go so far as to assume that because the words of a mark which he has never seen before have for him a quality connotation-Blue Ribbon, Gold Seal, A-1-a product bearing that mark is of acceptable quality.

Neither of these consumer assumptions is generally a useful means of making either efficient or risk-reducing purchasing decisions. Consumers must be willing, at times, to presume that the product of a firm is acceptable on the ground that the firm has in the past produced another product acceptable to themselves or others.

\section{III}

A trademark can continue to remind consumers of past consumption experiences despite changes in the ownership, management or control of a particular firm, and the needs of consumers can be served by the continued use of the mark in the market place, regardless of changes in the fortunes of the men-owners, managers and workers-through whom the firm accomplishes its tasks. Even simple,

- See Note, Quality Control and the Antitrust Laws in Tradenark Licensing, 72 YALE L.J. 1171, 1188-89 (1963).

10 See Isaacs, Traffic in Trade-Symbols, 44 Harv. L. Rev. 1210, 1220 (1931); cf. Brown, Advertising and the Public Interest: Legal Protection of Trade Symbols, 57 YALE L.J. 1165, 1187-89 (1948).

11 This last example clearly fits into the "general" list, but it also suggests that a consumer reacting in that way has specific information about a particular firm-a firm he has "humanized."

That consumers "humanize" firms seems clearly established. See, e.g., Spector, Basic Dimensions of the Corporate Image, 25 J. Marketrng, Oct. 1967, at 47. Consumers also form childhood preferences for particular firms which exert considerable influence upon later purchasing behavior. See Guest, Brand Loyalty Revisited: A Twenty-Year Report, 48 J. ApPLIEd Psychology 93 (1964).

12 See Grismore, The Assignment of Trade Marks and Trade Nanes, $30 \mathrm{MrCE}$. L. REv. 489, 494 (1932).

13 Id. 
individually owned firms have a potential existence in the market place which is independent of the life span of the proprietor. Joseph Ingels, a 19th century Indiana enterpreneur, provides an example. ${ }^{14}$

Ingels made and sold grain drills under the trademark HOOSIER from 1857 to 1876 . Letters patent protected portions of the drills after 1863, and gave them a certain distinction which apparently was found desirable by more than twenty thousand customers during the firm's nineteen-year tenure in the market. Moreover, the identifying symbol HOOSIER had a memory value which, when coupled with the reputed performance characteristics of drills bearing the mark, gave assurance that at any point in time HOOSIER drills would attract consumers for an additional period of time.

In 1876, probably for reasons of health, Joseph Ingels stopped doing business and, early in 1877 , perhaps realizing that his disability would prevent him from resuming, he transferred his rights in the unexpired patents and in the trademark HOOSIER to another. The goodwill symbolized by the trademark HOOSIER continued to exist after 1876, when Ingels withdrew from the market place; at the time he stopped production and transferred the patents and trademark, there were consumers willing to rely on the mark HOOSIER as a guide to purchasing a drill.

Though one might assume that in most cases the retirement of the owner of a "one man business" would have more of an impact on the policies and practices of the firm than would the retirement of a large corporation's executive, much can be said from the consumer's point of view for permitting Ingel's transferee to take up and use the HOOSIER mark. Since the transfer of marks with the transfer of businesses saves consumers the effort of keeping track of a changing pattern of symbols for product markets, the transfer of the mark HOOSIER presumably saved consumers from learning a new calculus of symbols for the drill field. There is, of course, a chance for dashed expectations when new owners use old marks, but if a basic goal is to provide consumers with symbols as devices for saving energy in the market place, then permitting owners of marks to transfer them with the business contributes to the energy-saving capacity of the system as a whole.

In the HOOSIER example, the matter of succession of owners would have been immaterial to consumers for whom the mark had a general quality connotation, if Ingels had transferred patents, marks, plant and equipment. The source to be rewarded or avoided then would have been unchanged despite the change in ownership, and it

14 The saga of Joseph Ingels can be gleaned from Julian v. Hoosier Drill Co., 78 Ind. 408 (1881). 
reasonably could be expected that in the period shortly after the transfer, consumers' expectations would be as likely to be served by a HOOSIER drill made by Ingels' successor as by a drill made by Ingels.

The transfer of trademarks is convenient, although not essential to the functioning of the market place. While the successor could be required to enter the market under his own symbol, permitting him to market drills under the old mark provides many consumers with easy access to the product of the firm which they prefer to patronize.

Indeed, the case of Joseph Ingels provides a relatively difficult test for a policy favoring transferability of marks. As ownership of business becomes dispersed and as ownership of the mark is seen as lodged in the firm rather than in the owners of the firm, it becomes easier to see the continuity of the firm and to support a policy of permitting marks to continue functioning as source symbols despite turnovers in ownership interests in the firm.

The Stillman-Carmichael partnership, which did business in Rhode Island in the 1870's, provides another example. In 1871 one partner died and three of the remaining five partners bought his interest. Later one of the remaining partners bought out the others and, after continuing the business for four years, sold it and the mark, STILLMAN \& CO., to a different firm, containing no members of the old firm. The purchaser continued making the same product, linseys, at the same quality, but at a different mill.

The Rhode Island court held that the new firm was entitled to use the mark of its predecessor, as the successor to its business. ${ }^{15}$ The transfers of interest among the original partners in the old firm were not thought to cast any doubt upon the propriety of the continued use by either the old or new firm of the mark originated by the first Stillman-Carmichael partnership. The court perceived that since the new firm had succeeded the old one, use by the new firm of the old firm's mark contributed to, rather than detracted from, order in the market place.

The idea of succession seems to be vital to the conclusion that transfer of marks is appropriate, for transfer of the mark to one who has not succeeded to "the business" gives rise to potential confusion in the market place. Where a brewing company liquidates its business, for example, selling the real estate to $A$, the equipment to $B$ and the trademark to $C,{ }^{16}$ it seems safe to assume that $C^{\prime}$ 's use of the old mark will mislead those consumers relying on the mark as a guide to purchasing decisions, because the product bearing the mark, coming from 
a firm having no continuing link with the former mark user, will not have the supposed relationship with past consumption experiences.

Traffic in trade symbols unconnected to underlying goodwill is unacceptable, not only because it leads to confusion, but because it leads to confusion which courts, keying as they do, only on cases and controversies, are ill-equipped to eliminate. But the consumer can benefit where a transfer of mark ownership accompanies and is incidental to a change in control of all of the assets of a firm. One might even argue that in cases where succession is clear, failure to transfer the mark would be inappropriate, both because a continued use of the mark by the transferor of the business would deceive consumers and a complete withdrawal of the mark from use by anyone would inconvenience them.

Courts are disposed to measure the legality of mark transfers by analyzing the function of the mark before and after the transfer. Professor Grismore long ago noted this instinct of the courts for a functional analysis, suggesting that a mark transfer is good, regardless of the quantum of tangibles accompanying the transfer, if the mark connotes the same thing to consumers after the transfer as before. ${ }^{17}$

Of course hard cases remain. Often a mark means different things to different consumers. As applied to cologne, for example, the mark 4711 may mean "cologne with this mark gave me satisfaction before" to some; it may mean, at the same point in time, "cologne with this mark was made according to a secret formula developed in Germany" to others. In the 1920's, two firms asserted rights in the mark 4711, then famous for cologne: Firm 1 succeeded to all of the assets of the firm which developed 4711 cologne, except the secret formula for producing the cologne; Firm 2 succeeded to the secret formula, but not to equipment, plant, inventory or personnel. ${ }^{18}$

It may have been that Firm 1 could produce a cologne enough like the old product so that customers with general expectations about quality, not based on knowledge of a secret formula, would get what they expected. It also may have been true that consumers for whom the formula was important would find their expectations defeated even if Firm 1's cologne was the laboratory equivalent of the cologne made with the secret formula.

Presumably problems such as the one in the 4711 case do not arise often enough to cast doubt upon the general policy favoring long service in the market place for marks having general quality connotations for most consumers. Perhaps fact patterns like that in the

17 Grismore, supra note 12 , at 494-503. 1930).

$18 \mathrm{See}$ Mulhens \& Kropff, Inc. v. Ferd. Muelhens, Inc., 43 F.2d 937 (2d Cir. 
4711 case can be dealt with by casting the burden upon one challenging the transfer to show that, for a substantial number of consumers, the mark as used by the successor firm misrepresents the nature of the product bearing it. Perhaps rights and remedies can be made to depend on the court's judgment about the number of consumers served and disserved by the new use of the old mark.

The divestiture of a department, division or subsidiary by a complex, multi-function firm probably poses the most recurring threat of injury to consumer expectations in the present economy. If firm $X$ produces a raw material that it sells under mark $A$ and a finished product that it sells under mark $B$, it may choose, for one reason or another, to divest itself of either the raw material business or the product line. Since some consumers who have purchased a raw material marked $A$ or an end product marked $B$ will have an interest in returning to or avoiding raw material $A$ or end product $B$ in the future, their interest will be served if firm $X$ disposes of the mark along with the part of the business sold. ${ }^{19}$

If one assumes that few consumers were aware that firm $X$ did business under both mark $A$ and mark $B$, then there is no potential for harm to consumer source associations when firm $X$ divests itself of one of its lines accompanied by the mark, since thereafter few consumers will suppose that a connection exists between the quality of raw material $A$ and the quality of end-product $B$. If firm $X$ is the General Electric Company, however, and it divests itself of its light bulb business accompanied by the right to control the use of the General Electric symbol in the light bulb field, while retaining rights in the mark in other fields, there will be great potential for consumer confusion. The General Electric symbol probably has strong, specific source connotations for the many consumers who know that the General Electric Company operates in many product and service markets. It also may be assumed that the General Electric Company is aware of these trademark connotations, and that it therefore would be unwilling to entrust control of its mark to one who, by activity in the light bulb market, might devalue the mark in those markets where it is still controlled and used by General Electric. In these two cases, the consumer interest is best served if firm $X$ accompanies the transfer of its raw material business or product line with a transfer of rights in the appropriate mark and, if General Electric, in withdrawing from the light bulb field, does not transfer rights in the General Electric symbol to the successor firm.

18 See Canadian Club Beverage Co. v. Canadian Club Corp., 268 Mass. 561, 168 N.E. 106 (1929); cf. Tetra Pak Co. v. Schneider, 125 U.S.P.Q. 460 (Tm. T. \& A. Bd. (1960); Witthaus v. Braun, 44 Md. 303 (1876). See also R. Dole, TERRItortaI, TRADEMARK Rights and tHe ANTITRỤst Laws 94 (1965). 
As a practical matter the self-interest of enlightened businessmen usually can be depended upon to coincide with the interest of consumers in maintaining orderly markets. In cases like those discussed above, it can be assumed that the mark owner's evaluation of the impact of the proposed mark transfer upon future relations with customers of its undivested lines will contribute significantly to the decision to transfer or not to transfer the trademark along with the assets.

The businessman's desire to develop and retain loyal customers can also be depended upon to safeguard consumers from fraud or deception when $A$ sells his entire business to $B$. There is, in such a case, danger that $B$ will abandon $A$ 's standards, put out a shoddy product, exploit customers who rely on $A$ 's mark until it no longer symbolizes $A$ 's former goodwill and then terminate the business. But this rarely occurs--perhaps because $B$ will have paid too much for $A$ 's goodwill to risk short-run exploitation and, perhaps, because acquiring a firm with brand-loyal customers, by definition, involves the kind of investment that requires the participation of men or institutions not motivated toward exploitation, even in the long run. ${ }^{20}$ Although the consumer who relies on marks as indicators of quality always runs the risk that the product purchased will have been downgraded intentionally by the producer, reported instances of cases involving quality change in trademarked products are few. ${ }^{21}$ The main point, however, is not that producers seldom defraud consumers by sudden and substantial changes in the quality of trademarked products, but that

20 See J. Galbratth, The New Industrial State 108-78 (1967); Galbraith, Market Planning and the Role of Government: The New Industrial State II, 219 The Atlantic, May, 1967, at 69. Professor Berle has suggested that businessmen understand that the transfer of control of a firm carries with it an ethical duty to shareholders, labor, consumers and management on the part of the seller "to assure himself that his successors conform . . . to minimum standards of character and responsibility." Berle, "Control" in Corporate Laze, 58 Colum. L. Rev. 1212, 1220 (1958).

21 Doubtless the number of reported cases does not reflect the number of instances of change in quality, since both consumers and competitors are unlikely to sue-consumers because litigation is seldom worth the trouble and competitors because it is difficult for them to state a cause of action.

The FTC can and does police such conduct. In Royal Baking Powder Co. v. FTC, 281 F. 744 (2d Cir. 1922), the court affirmed an order declaring that use of a brand name identified with cream of tartar baking powder on phosphate baking powder was an unfair method of competition. In Waltham Watch Co. v. FTC, 318 F.2d 28 (7th Cir. 1963), the FTC ordered defendant to cease authorizing the use of the word "Waltham" on watches imported from abroad, except with the disclaimer "not manufactured by Waltham Watch Co. of Massachusetts." The FTC felt that consumers would be deceived (and competitors disadvantaged) if a mark made famous by over 100 years of use on watches made in Massachusetts was suddenly applied to watches of German origin.

The courts also police conduct resulting in quality changes. An alternative holding in Independent Baking Powder Co. v. Boorman, 175 F. 448 (D.N.J. 1910), was that plaintiff forfeited whatever mark rights it had by changing the basic ingredient in its baking powder from alum to phosphate. In Renaud Sales Co. v. Davis, 22 F. Supp. 703 (D. Mass. 1938), modified, 104 F.2d 683 (1st Cir. 1939), a plaintiff was deemed not entitled to the aid of equity in policing its mark rights, because it had diluted its product. It began selling $1 / 4 \mathrm{oz}$. of perfume for $39 \xi$, where before it had sold 1 oz. for $\$ 10$. 
the incidence of such occurrences would seem not to be related significantly to transfers of control of firms.

\section{IV}

A major problem of quality control of trademarked products is created by the fact that a product will often contain parts manufactured by a sub-contractor with whom the mark owner's relations are only contractual.22 Such situations are similar to the case of the markowning retailer who has a relatively stable relationship with his sources of supply. ${ }^{23}$ The mark-owning retailer can control the nature and quality of the supplied goods by enforcing the terms of his contract; he presumably will use his supply contracts to provide consumers with goods of constant quality and thus make his mark a reliable vehicle for making purchasing decisions.

22 ". . . [O]rigin is not limited to the actual manufacture of every constituent element of the trade-marked article." American Thermos Bottle Co. v. W. T. Grant Co., 279 F. 151, 156 (D. Mass. 1922). Firms often contract out to independent units some of the functions involved in manufacturing the entire product. A random group of labor cases, in which a dispute arose due to subcontracting while a union agreement was in effect, indicates the breadth of subcontracting activities: delivery service, Alan Wood Steel Co., 44 Lab. Arb. 722 (1965); packaging, Kaiser Alum. \& Chem. Corp., 43 Lab. Arb. 307 (1964) ; manufacturing, United States Steel Corp., 44 Lab. Arb. 317 (1965) ; repair work, Kennecott Copper Corp., 148 N.L.R.B. 1653 (1964); and maintenance services, UAW v. Webster Elec. Co., 299 F.2d 195 (7th Cir. 1962).

At one time the vacuum bottle marketed under the well-known THERMOS trademark consisted of a container made in Germany and a filler from Japan, combined in the United States, sold under the label "made at Norwich" and marketed under the slogan "American-made goods for American people keep American workmen busy." See American Thermos Bottle Co. v. W. T. Grant Co., supra at 157-58.

Many of the components of complex items such as automobiles or airplanes are manufactured for the mark owner by independent sources. Much of the annual tooling effort in the auto industry is conducted not by the auto firms themselves, but by independent local shops. See W. Paton \& $R$. Dixon, Make-or-Buy Decisions In Tooling for Mass Production (1961) (Mich. Bus. Rep. No. 35). Parts ranging from finishes and fabrics, see, e.g., United States v. E. I. DuPont De Nemours \& Co., 353 U.S. 586 (1957), to crank shafts and tires, see, e.g., C. EDWARDS, DyNaMrcs of THE United States Automobile Industry 149-69, 251-53 (1965) ; G. Means, Pricing Power and THE PUblic InTERest 198-207 (1962), are contracted out to various independent sources.

In the airplane industry, the primary manufacturers contract out the manufacture of such items as aircraft bolts, plexiglass, plastic knobs, fire control systems, landing gear apparatus and fuselage sections, see, J. DAY, SUBContracting Policy IN THE AIRFRAME INDUSTRY 117, 120-40, 148-53 (1956), and they contract both with companies having a permanent connection with the primary company and with the industry and with temporary sources-job shops having in some cases but a fleeting relation with either the primary company or the air frame industry. Id. at 32-33, 116.

In retailing, as is well known, mark owners performing only a marketing function buy canned goods, HML Corp. v. General Foods Corp., 365 F.2d 77 (3d Cir. 1966); dairy products, FTC v. Borden Co., 383 U.S. 637 (1966); auto supplies, Atlantic Refining Co.v. FTC, 381 U.S. 357 '(1965), rehearing denied, 382 U.S. 873 (1965); liquor, Ph. Schneider Brewing Co. v. Century Distilling Co., 107 F.2d 699 (10th Cir. 1939); clothing, Rosen v. Furmbilt Stores, Inc., 103 F.2d 294 (10th Cir. 1939); tobacco products, Witthaus v. Braun, $44 \mathrm{Md}$. 303 (1876); record players, H. H. Scott, Inc. v. Annapolis Electroacoustic Corp., 195 F. Supp. 208 (D. Md. 1961); shoes, United States Rubber Co., 46 F.T.C. 998 (1950), and scores of other items from manufacturers; these mark owners impress their mark upon the goods.

23 See, e.g., Witthaus v. Braun, 44 Md. 303 (1876). 
The process by which the mark owner gets goods bearing his mark to the point of purchase is an integrated process of assembly which he controls, either directly as owner-employer or indirectly as contractor-purchaser. To both the mark owner and the consumer, the plant of each sub-contractor with whom the mark owner deals becomes, in effect, one of the departments whose efforts are coordinated to produce a finished, trademarked product. ${ }^{24}$

For the consumer, the fact that a mark owner may do business without ownership control over all of the factors of production means that the source represented by the mark is not a single, static, legal entity. Instead it is a changing complex of legal and personal relations. $^{25}$ But this does not impede the consumer in his use of source symbols as aids in making purchasing decisions. In fact, for most purchasing decisions the consumer does not care about the organization chart of the firm or firms which brought the product to market. He knows-although he does not think of it-that firms have turnovers in personnel, change raw material sources and award subcontracts. ${ }^{26}$ The consumer wants a product for which there is a reasonable expectation that present quality will be like the quality of past products bearing the same mark. A reasonable expectation of consistent quality is possible if the business using the mark has sufficient cohesiveness and continuity of purpose to give it a nexus with the past and the future.

The concept of source seems broad enough to include situations where the trademark owner exercises quality control at the end of a procedure in which important manufacturing functions have been delegated to other independent firms, since it is realistic to view the other firms as departments in a loosely organized venture coordinated by the mark owner. Where the finished products come within the physical control of the mark owner before they are offered to consumers, it is unimportant whether the various units contributing to the product are contract-controlled or ownership-controlled. The mark owner quite reasonably can be regarded as the source under either form of organization. The concept of source is also broad enough to

24 See, e.g., G. Anyon, Managing an Integrated Purchasing Process 96 (1963).

25 This dynamic source is not, in fact, without responsibility. If it comes to that, the law will point to someone whom the consumer can hold for injury-causing defects in the marketing or production processes. And common sense suggests that cofects in the marketing or production proces, in addition, hold such multi-unit "sources" responsible for defeated expectations by thereafter avoiding products bearing the offending trademark.

${ }_{20}$ Cf. Bostitch Trademark, [1963] R.P.C. 183 (Ch. 1963), a case involving a challenge to an American firm's marketing program in England, in which Justice LloydJacob pointed out that neither the British Trademark Act nor general principles of trademark law requires the mark owner to refrain from varying manufacturing or marketing procedures. The Justice observed that a mark owner may move his plant from one place to another, change subcontractors or arrange for final assembly by someone of his choice. 
embrace arrangements where independent firms perform functions which influence product quality after the product has left the mark owner's premises and is thus beyond the physical control of the managers and employees of the mark-owning firm. Theoretically, under such a concept of source, the community of firms involved will probably have a similar interest in the long run quality and success of the product, regardless of their position in the assembly process. A sub-contractor generally is interested in seeing that the end product is successful so that demand for his component increases, and he generally is concerned about meeting the mark owner's quality specifications so that his position as supplier will be secure against the efforts of his competitors to dislodge him.

The interests of the mark owner are not affected by the way he organizes his relations with sub-contractors. The marks owner's primary interest is always the success of his product, and where product success depends upon acceptable performance by firms associated contractually with the venture, the mark owner probably will set forth rigorous performance standards in his contract specifications and force adherence to those standards. His stake in the performance of his subcontractors is not lessened when they perform their tasks after the product has left his premises.

Despite the concert of interests between the mark owner and subcontractor, there may be more risk for the consumer that product quality will vary substantially where some or all of the manufacturing process takes place at the plant of a sub-contractor. Courts and agencies may assume that it is more likely that a non-owner-mark-user will vary quality than that an owner-user will vary quality. It is diffcult to label such an assumption unreasonable. ${ }^{27}$ Presumably one who contributes to a product marketed under a mark owned by another does not have the same stake in preserving the goodwill of the enterprise as the mark owner, if only because contract relations are severable and sub-contractors replaceable. ${ }^{28}$ Accordingly, where the mark owner organizes a manufacturing-marketing effort in which manufacturing functions are performed by independent firms standing between the mark owner and the consumer in the assembly process, a requirement that the mark owner hold contributing independent firms to strict standards of performance may help to insure that the use of such an organizational scheme will not increase the consumer's risk of defeated expectations. ${ }^{29}$

27 See Lahart, Control-The Sine Qua Non of a Valid Trademark License, 50 TRADEMARK REP. 103, 106 (1960).

28 See Whitman, Trademark Traps, 42 Trademark ReP. 583 (1952).

29 Cf. Shniderman, Trademark Licensing-A Saga of Fantasy and Fact, 14 LAw \& Contenrp. Prob. 248, 262-64 (1949). 
In administering such a requirement, the courts should focus on the presence or absence of the exercise of quality control, and not on the presence or absence of defeated consumer expectations. This would provide an administrable and effective safeguard against the possibility of defeated expectations, without unduly burdening mark owners or forcing courts into difficult inquiries about the quantity and quality of consumer expectations.

Conceivably cases will arise where a complete failure on the part of a mark owner to control the quality of products to which a licensee affixes the owner's mark would be unlikely to lead to fraud, deception or defeated expectations in the market place. Mark owner $A$ might, for example, license $B$ to distribute heating oil to consumers, using the mark SOMERLITE. On the one hand, $A$ could tell $B$ to buy oil that meets certain specifications and $A$ might check $B$ 's purchases periodically to see that $B$ was following directions. Clearly, $A$ would be controlling the nature and quality of the goods sold under his mark. Alternatively, $A$ could simply tell $B$ to buy oil when and where $B$ chose, in which case $B$ would be marketing, under $A$ 's mark, oil with which $A$ had no connection whatsoever, generating a potential for consumer deception. Any consumer who purchased SOMERLITE oil supposing it to be the product of one firm, would, in fact, be purchasing a product which came, not from one firm, but from one of two different and independent firms. For such a consumer, the risks that product quality will depart substantially from that which normally might be anticipated (due to changes in ownership, management, production procedures and so on) will be much higher than the consumer could have expected from a survey of the marks confronting him.

It might be argued that since heating oil is heating oil, and since, the sources of oil are relatively few in number and all known to $A$, $A$ 's grant of wide discretion to $B$ would lead to no differences in the actual quality of the oil sold under the SOMERLITE mark than would have occurred had $B$ been controlled more rigorously. But where the mark means only that oil is selected, rather than manufactured, by the mark owner, the consumer is entitled to suppose that the mark owner brought his skill and his knowledge to bear in selecting the product. ${ }^{30}$

One of the early Coca-Cola cases illustrates this point. The CocaCola Company sought to enjoin defendant from manufacturing a beverage produced according to the Coca-Cola formula, made from genuine syrup and marketed with genuine bottle crowns and labels. The court granted the injunction, reasoning that even if defendant sold a product which was physically identical to the product marketed by

30 See Somerlite Ltd. v. Brown, 51 R.P.C. 205, 224-25 (Ct. App. 1934). 
bottling companies licensed by plaintiff, the defendant nevertheless was deceiving consumers because it was not selling a product which was inspected and guaranteed by Coca-Còla to be wholesome, palatable, uniform, clean and excellent. ${ }^{31}$ The trademark COCA-COLA was seen, in other words, as standing not only for a product of a certain quality, but for a product which had been subjected to a particular program of quality control.

This reasoning is analogous to the classic passing off doctrine: if $B$ sells his product as $A^{\prime}$ s, $B$ has committed a tort, ${ }^{32}$ even if $B$ 's product is less expensive and superior to $A$ 's. While in such a transaction the consumer may get a better product for less money, he is nevertheless deceived, for he asked for $A$ 's product and received $B$ 's. The same sort of harm is present in both the SOMERLITE and COCA-COLA examples-consumers were being confronted with two quality control programs where they reasonably supposed only a single program to exist, ${ }^{33}$ and were being misled into buying a product supposing it to be connected with $A$ 's quality control program when it was in fact connected with $B$ 's.

\section{V}

If trademark licensees submit to the mark owner's control to insure that consumers who rely upon marks as guides to purchasing decisions find the licensed mark useful, then the practice of trademark licensing need not prove inconsistent with basic trademark philosophy. ${ }^{34}$ But basic trademark philosophy would seem to require that mark owners exercise enough supervision over licensees to prevent deviations in production procedures which might impair the usefulness of the mark to the consumer. A requirement of supervision, in turn, requires that individuals or institutions be given authority to police the requirement and requires norms against which conduct can be measured and penalties for failure to meet these norms assessed.

Not surprisingly, the first institution given responsibility for policing mark licensing arrangements in the United States was the court; the judicial process has borne the burden of developing rules and sanctions for licensing arrangements, although the policing task is shared in a small way by the Patent Office and by the Federal Trade Commission. Moreover, because trademark licensing is a relatively

31 Coca-Cola Co. v. Bennett, 238 F. 513 (8th Cir. 1916).

32 See Croft v. Day, 7 Beav. 84, 89-90, 49 Eng. Rep. 994-997 (Rolls Ct. 1843); cf. Burgess v. Burgess, 3 De G. M. \& G. 896, 43 Eng. Rep. 351 (Ch. 1853); Welch v. Knott, $4 \mathrm{~K}$ \& $\&$ J. 747, 751, 70 Eng. Rep. 310, 312 (V.C. 1857).

33 See Coca-Cola Co. v. J. G. Butler \& Sons, 229 F. 224, 230 (E.D. Ark. 1916).

34 "Thus it is clear that contrary to defendant's contention, registered marks are franchisable by the owner thereof." Boersma v. Executive Travel Club, Inc., 256 F. Supp. 289, 291 (D.D.C. 1966). 
recent development, ${ }^{35}$ the courts have not yet devised a complete system of rules for its regulation. For example, it has only recently become established that a written contract, in which quality standards are expressed as contractual obligations, is not a requisite of a valid licensing arrangement. In 1959, both the United States Court of Appeals for the Second Circuit ${ }^{36}$ and the Court of Customs and Patent Appeals ${ }^{37}$ emphasized that a licensing arrangement can comply with the requirement that a licensor control the nature and quality of products marketed under his mark, even where there are no express contractual provisions setting forth standards and giving the mark owner a right to inspect and supervise his licensee's activities. ${ }^{38} \mathrm{~A}$ writing would be an acceptable requirement if it eased the task of administering licensing relationships, but it would not; ${ }^{39}$ licensing arrangements are usually in writing in any event, yet courts have to focus, in most cases, as they should, upon the actual relationship, rather than the writing. The slight administrative gain from requiring licenses to be in writing would be more than offset by the cost of removing judicial protection from marks whose owners have controlled their use without a writing. ${ }^{40}$

It is not yet clear that the courts have rejected the proposition that a writing will save a licensing arrangement in which there is in fact an absence of control. The courts in time must reject this idea, because accepting the existence of a writing as an end to an inquiry into the acceptability of the licensing arrangement would be

35 With the exception of Marsh v. Billings, 7 Cush. 322 (Mass. 1852) ; Meridian Brittania Co. v. Parker, 39 Conn. 450 (1872); Winsor v. Clyde, 9 Phila. Rep. 513 (C.P. 1872); Mattingly v. Stone, 12 Ky. L. Rptr. 72, 12 S.W. 467 (Ct. App. 1889), opirion on motion for rehearing, 14 S.W. 47 (1890); Batchellor v. Thompson, 93 F. 660 (2d Cir. 1899); R. Heinisch's Sons Co. v. Boker, 86 F. 765 (S.D.N.Y. 1898); and, perhaps, on its alternative rationale, Weener v. Brayton, 152 Mass. 101, 25 N.E. 46 (1890), all other reported opinions dealing with trademark licensing occur in the twentieth century.

${ }^{36}$ Cf. Dawn Donut Co. v. Hart's Food Stores, Inc., 267 F.2d 358, 368 (2d Cir. 1959) (licensor defeated counterclaim in infringement suit).

37 Cf. Sealy, Inc. v. Simmons Co., 265 F.2d 934, 937 (C.C.P.A. 1959) (licensor opposed application for federal registration).

38 See Progressive Welder Co. v. Collom, 125 F. Supp. 307 (D. Minn. 1954) (licensor defeated former licensee). The Trademark Trial and Appeal Board also clearly has taken the position that the Lanham Act does not require that licenses be in writing. See McCormick \& Co. v. Summers, 141 U.S.P.Q. 258 (Tm. T. \& A. Bd. 1964), rev'd on other grounds, 354 F.2d 668 (C.C.P.A. 1966); Clarke v. The Sanderson Films, Inc., 139 U.S.P.Q. 130 (Tm. T. \& A. Bd. 1963). See also Sealy, Inc. v. Simmons Co., 265 F.2d 934 (C.C.P.A. 1959).

39 But see Robinson Co. v. Plastics Research \& Dev. Corp., 264 F. Supp. 852 (W.D. Ark. 1967).

40 Particularly likely to be caught by a technical rule focusing on a writing rather than on reality are mark owning firms which incorporate subsidiaries and permit them to use a mark without formally licensing its use. See, e.g., Sterling Drug Inc. v. Lincoln Laboratories Inc., 322 F.2d 968 (7th Cir. 1963); United States Ozone Co. v. United States Ozone Co. of America, $62 \mathrm{F.2d} 881$ (7th Cir. 1932); Socony-Vacuum Oil Co. v. Atomol Mfg. Co., 58 U.S.P.Q. 497 (Comm'r. 1943); Applications by Kidax (Shirts) Ltd., [1959] R.P.C. 295 (Ch. Div. 1959). 
an abdication of responsibility by the courts, whose task is to protect consumers in the markets by looking to the actual quality control exercised. In Alligator Company v. Robert Bruce, Inc., ${ }^{41}$ the court stated that the fact that a licensing agreement establishes an appropriate relationship between licensor and licensee on paper is not determinative of the acceptability of the relationship in fact; it is what the parties actually do in carrying out the agreement and not what the agreement entitles them to do which is of public concern. ${ }^{42} E . I$. Dupont De Nemours \& Co. v. Celanese Corp. ${ }^{43}$ is probably the most famous case in which a court appears to pay undue deference to a writing. DuPont petitioned to cancel the Celanese Corporation's registration of CELANESE for dyestuffs. DuPont's challenge was based on allegations that American Aniline, the Celanese Corporation's licensee, marketed products under the mark CELANESE, without mention of the licensing arrangement, in ways which suggested that Aniline owned the mark, and that the Celanese Corporation itself knew about and approved the marketing method. DuPont theorized that since Aniline's marketing technique resulted in the mark CELANESE no longer indicating the Celanese Corporation name, the Celanese Corporation's federal registration was invalid and subject to cancellation.

DuPont's theory was clearly deficient, since it supposed that the requirement that a single mark represents a single program of quality control in the market, in turn, required that the control be identified by name, or, at least, not misidentified. The court should have ruled that the petition for cancellation would not lie because the existence of a uniform program of quality control for goods marketed under the CELANESE mark was not disputed. The court announced, instead, that a licensing agreement in which the licensor reserves the right to continue the use of the mark and which provides that the agreement may be terminated by the licensor is not an abandonment of the registered mark. "It is obvious," the court concluded, "that the license agreement is not a naked license agreement, and that appellee

41176 F. Supp. 377, 379 (E.D. Pa. 1959).

42 But see Robinson Co. v. Plastics Research \& Dev. Corp., 264 F. Supp. 852 (W.D. Ark. 1967), where the parties to a written mark license omitted all references to control, leaving the licensor without an explicit contractual right to exercise any control over the nature and quality of the goods produced and sold under the license. The court ruled that the licensor granted a naked license and in so doing abandoned his rights in the licensed mark.

The court, perhaps without considering the full implication of its statement, said it is the right to control rather than the actual exercise of control which determines whether a license is valid. The court then stated, more plausibly, that if the licensor attempted to enforce controls upon the licensee in court, "he would doubtlessly be met with the parol evidence rule and would not be allowed to amend the original duly executed document. . ." Id. at 864 . (Even in an infringement suit?)

43167 F.2d 484 (C.C.P.A. 1948). 
has not abandoned its mark. . . ." Although the court stated that there were no allegations that the quality control terms of the agreement were not fully carried out by both parties, the tenor of the opinion may lead the casual reader to the misunderstanding that the presence of a writing showing the licensor's intent to continue to use the mark will shield the licensor from a judgment of abandonment (that is, forfeiture) of mark rights regardless of the state of the record on the issue of actual control.

Another case placing great emphasis on the terms of the writing involved a licensing arrangement between Land O'Lakes Creameries and a Baltimore food broker. ${ }^{45}$ Land O'Lakes licensed the broker to use the mark LAND O'LAKES on canned goods in 1929, and for thirty-five years thereafter the broker procured a full line of canned goods from various canners which he marketed under the LAND O'LAKES mark. The mark owner exercised no positive control over its licensee or his sources, but the district court felt that the contract between the parties justified the mark owner's reliance on the licensee's quality control program and satisfied the requirement that the mark owner control the licensee. The court of appeals affirmed, stressing that a dearth of complaints about quality during the forty-year period in which the broker used the mark (on labels containing the mark owner's address) justified the mark owner in equating reliance upon the licensee's control over quality with actual supervision of the licensee.

Wolfie's Restaurant, Inc. v. Lincoln Restaurant Corp. ${ }^{46}$ is similar, in that the court upheld a licensing arrangement in which the licensee was required only to continue to operate his restaurant as he had in the past and in which the licensor had a right to investigate the licensee's activities-a right unexercised at the time of suit, after two years. The court reasoned that the contract provisions, setting forth the status quo ante standard and the right to investigate, legitimated the arrangement, and ruled that proof of the failure of the licensor to investigate, standing alone, was of no legal significance.

The Wolfie's and Land O'Lakes opinions might stand for the proposition that the absence of proof of consumer dissatisfaction with the quality of the licensee's product renders insignificant proof that the licensor has not actually supervised the production processes of his licensee. Equating a contractual "right" to control, or (as one author

44 Id. at 488 .

45 Land O'Lakes Creameries, Inc. v. Oconomowoc Canning Co., 221 F. Supp. 576 (E.D. Wis. 1963), aff'd, 330 F.2d 667 (7th Cir. 1964).

46143 U.S.P.Q. 310 (N.Y. Sup. Ct. 1964). 
labels it, negative control), ${ }^{47}$ with actual or positive control, seems to put the courts in the difficult and administratively undesirable position of measuring injuries to consumer expectations rather than safeguarding consumer expectations by measuring the quantum of quality control exercised by the licensor. To suggest that a "right" to inspect the licensee's operation or a "right" to terminate the license ${ }^{48}$ for cause or at will is sufficient control over quality is to ignore the reason for imposing the requirement of control in the first place.

A licensee, it was earlier postulated, is somewhat more likely than a mark owner to vary product quality, giving rise to a requirement that a mark owner who chooses to license the use of his mark must eliminate this additional increment of risk to the consumer by supervising his licensee. But to permit the mark owner to supervise in the market place, rather than on the licensee's premises, is to run the risk that an irresponsible licensee will fill the market place with deficient products before the mark owner will be alerted to the need to halt his licensee's production process.

Mark owners prefer to supervise quality before goods reach the market place. For example, the Manischewitz people went to court to stop the distribution, under the Manischewitz mark, of a mere 525 cases of canned soup which had been rejected for not meeting Manischewitz quality standards, and which they feared might fail to fulfill consumer expectations. ${ }^{49}$ The Forstmann Woolen Company also has attempted to enjoin the use of its trademark on products made with Forstmann materials but not made under Forstmann supervision, ${ }^{50}$ and several similar suits have been brought by other corporations including the Coca-Cola Company. ${ }^{51}$ These cases evidence concern by mark

47 Woodward, Some Observations on Legitimate Control of the Nature and Quality of the Goods, 49 Trademark Rep. 609 (1959). In Ritz Associates, Inc. v. Ritz-Carlton Hotel Co., 19 App. Div. 2d 522, 138 U.S.P.Q. 404 (N.Y. App. Div. 1963) (per curiam), aff'd, 14 N.Y.2d 670, 198 N..E.2d 905, 249 N.Y.S.2d 873, 141 U.S. P.Q. 757 (1964), the court affirmed a lower court decision granting summary judgment, declaring a licensee free to discontinue paying a royalty for the use of the name RITZ TOWER. One of the alternative grounds for decision was that the licensor did not control the licensee's use of the mark. Judge Rabin dissented in part, saying that there were two questions of fact: whether a license providing for a revocation if the licensee fails to maintain a "high-class" hotel is without standards, and whether there was sufficient supervision even though the licensor entered no documents asserting positive action on its part.

48 See authorities cited note 47 sipra. 1949).

49 Manischewitz Food Prods. Inc. v. Rosenberg, 80 U.S.P.Q. 427 (E.D. Pa.

50 Forstmann Woolen Co. v. Murray Sices Corp., 144 F. Supp. 283 (S.D.N.Y. 1956) ; Forstmann Woolen Co. v. J. W. Mays, Inc., 89 F. Supp. 964 (E.D.N.Y. 1950); Forstmann Woolen Co. v. Murray Sices Corp., 10 F.R.D. 367 (S.D.N.Y. 1950); Forstmann Woolen Co. v. J. W. Mays, Inc., 71 F. Supp. 459 (E.D.N.Y. 1947).

51 E.g., Coca-Cola Co. v. Bennett, 225 F. 429 (D. Kan. 1915), rev'd, 238 F. 513 (8th Cir. 1916) ; Champion Spark Plug Co. v. Sanders, 331 U.S. 125 (1947) ; B. B. \& R. Knight, Inc. v. W. L. Milner \& Co., 283 F. 816 (N.D. Ohio 1922). 
owners that products likely to impair goodwill by disappointing consumers be kept out of the market place, and any legal formulation that focuses on the point of production only after defective products have found their way onto retailer's shelves is inconsistent with this concern.

In Coca-Cola Co. v. Bennett, ${ }^{52}$ the district court found against the Coca-Cola Company (and was reversed) when the company sought to enjoin a former licensee from continuing to use the COCA-COLA mark. The lower court reasoned that the defendant had acquired the basic ingredients in good faith and proposed to put them to the use contemplated by the parties at the time the Coca-Cola Company sold them to the defendant. The effect of the district court decision was to remand the Coca-Cola Company to the market place to judge the nature and quality of the former licensee's product there, with resort to the courts (presumably on an infringement theory) if the product marketed under the COCA-COLA mark turned out to be of unacceptable quality.

This form of quality control is exactly the type of control legitimated in the Land O'Lakes case. It is no control at all with respect to some quantity of output, and it subjects consumers to unnecessary risks of substantial quality deviations by disgruntled, careless or financially strapped licensees. From the consumer's point of view, the licensor must supervise quality in the licensee's plant and not in the market place.

The question of how much supervision is sufficient seems to be a difficult judicial question. In Purity Cheese Co. v. Frank Ryser $C o .{ }^{53}$ for example, plaintiff complained that defendant was infringing the mark MAY-BUD for cheese. Defendant moved for summary judgment on an unclean hands theory. Defendant alleged that plaintiff was not entitled to the aid of a court of equity to protect its mark, because the mark had been licensed to others whose use of the mark was not controlled by plaintiff. Plaintiff's bill of particulars admitted that plaintiff licensed its distributor to use MAY-BUD on cheese and that some cheese sold under the mark had been manufactured by companies other than plaintiff or its licensee and "plaintiff ha[d] no knowledge by whom." Judge Duffy granted defendant's motion, stating that when plaintiff permitted its licensee to use MAY-BUD on cheese supplied by sources unknown to plaintiff, plaintiff became party to a fraud on the public. The Seventh Circtiit reversed, ruling correctly that summary judgment was inappropriate because all that appeared was that cheese not of plaintiff's manufacture

52225 F. 429 (D. Kan. 1915), rev'd, 238 F. 513 (8th Cir. 1916).

5357 F. Supp. 102 (E.D. Wis. 1944), rev'd, 153 F.2d (7th Cir. 1946). 
was sold under plaintiff's mark, a fact not alone sufficient to deprive plaintiff of its mark rights.

While plaintiff's admissions indicate that it was probably derelict in supervising its licensee, they are not conclusive; plaintiff might have set standards for its licensee to follow in selecting cheese to be marketed under the MAY-BUD mark and might have checked to see that the licensee followed directions. Whether it did is the crucial question, a question unanswered by the papers before the trial court at the time of the motion for summary judgment.

But suppose the Purity Cheese case had gone to trial and the court had learned more about the actual relationship between the mark owner and its licensee. If the mark owner had proved the existence of a written agreement setting forth standards for the licensee and providing for on-the-premises inspection by the licensor and the defendant had proved nothing, should the court have drawn the inference that there was actual supervision? On the other hand, if the defendant had offered testimony that the licensor had not inspected the licensee's operation at all in the past six months, the past two years (as in Wolfie's) or since the beginning of the relationship (as in Land O'Lakes and Wolfie's), how should the trial court have reacted? Assuming that a court chooses to work with a rule requiring actual or point-of-production supervision, the answer may depend upon the length of time during which there was no inspection. In the Land O'Lakes case, the mark owner should have lost any rights it had to control the use of the mark in law, by failing to control the use of the mark in fact for many years. But in Wolfie's, only two years had elapsed. Does an "actual control" principle require inspection every year? Every five years? Is the requirement different for restaurants and motels, ${ }^{54}$ than for canned goods and donut mixes?

Courts generally have found it impossible to find insufficient supervision where there is evidence that there was at some time some actual

54 In Tisch Hotels, Inc. v. Atlanta Americana Motor Hotel Corp., 254 F. Supp. 743 (N.D. Ga. 1966), plaintiff, who operated AMERICANA hotels in Miami, New York and San Juan, enjoined defendant from making an infringing use of plaintiff's federally registered service mark in connection with defendant's Atlanta motel. In 1962, defendant informed plaintiff that defendant recommended plaintiff's motels to its customers and made reservations for them at plaintiff's motels as often as possible. Plaintiff responded by asking defendant to continue to advise all guests of plaintiff's hotels and in return plaintiff would see that guests requesting bookings in Atlanta would be put in defendant's motel. The court labeled this arrangement a valid license of plaintiff's mark, revocable at will. It certainly set forth no standards, and there appeared to be no supervision. Perhaps plaintiff satisfied the requirement of control by revoking the license before the period expired during which a "first exercise of actual control" was still legally possible. See Geo. A. Hormel \& Co. v. Hereford Heaven Brands, Inc., 341 F.2d 158, 160 (C.C.P.A. 1965), where the court, speaking to the assertion that Hormel abandoned its mark by failing to control a recently acquired licensee, agreed with the conclusion of the board "That "it cannot at this time be said that Hormel has failed to exercise such control' as to preclude its right in this opposition." Compare cases where the mark owner acquiesces in an infringing use of his mark for a period of time, then successfully asserts a claim against the second user: e.g., Ralston Purina Co. v. Midwest Cordage Co., 153 U.S.P.Q. 
supervision. In Wolfie's the court was unwilling to rule that a complete absence of actual supervision was insufficient. In Keebler Weyl Baking Co. v. J. S. Ivins' Sons, Inc., ${ }^{55}$ the defendant in the infringement suit challenged plaintiff's licensing system. Plaintiff was one of sixteen wholly-owned subsidiaries of United Biscuit Company and permitted seven of the other subsidiaries to use its mark. The record showed that at the inception of each licensor-licensee relationship, plaintiff sent an employee to show each of the seven how to manufacture the product that was to bear the licensed mark. The court could see no imposition upon the public and no element in the scheme which would impair plaintiff's right to exclude others from using its mark.

The determinative factors for the court were the general control of United Biscuit over plaintiff and the licensees, and plaintiff's use of an employee to give instructions to the licensees at the beginning of the relationship. ${ }^{56}$ The opinion indicated that plaintiff and some of its licensees had been independent of the central holding company at one time, but failed to discuss the degree to which the parent participated in the management decisions of its subsidiaries or the amount of time devoted to supervision of licensees by plaintiff's employee. The

73 (C.C.P.A. 1967). Also see Baxter Laboratories v. Don Baxter, Inc., 87 U.S.P.Q. 122 (Comm'r 1950), where an application for a trademark registration, alleging a controlled use of the mark by a related company, was denied, the Commissioner noting that the allegation by the applicant of continuous quality control of the licensee's output was not supported by evidence of contimuous checking of samples or continuons checking at the user's plant. The standards in Playboy Club licenses apply to decor, design, quality and quantity of food, beverages and entertainment. Licensees are also provided with an operating manual. The Playboy Club licensees are policed by the licensor's agents who regularly visit the clubs and report the degree of compliance with standards. See Turner v. HMH Publishing Co., 380 F.2d 224 (5th Cir. 1967).

557 F. Supp. 211 (E.D. Pa. 1934).

56 Compare two decisions under British law. In Bowden Wire Ltd. v. Bowden Brake Co., 31 R.P.C. 385 (H.L. 1914), a company licensed its subsidiary to use the parent's trademark and was deemed to have thereby lost its rights in the mark. In In re Trademark "Radiation", 47 R.P.C. 37 (Comptroller General 1930), the mark owner held virtually all of the shares of a group of associated companies who manufactured the product to which the mark was attached. The Comptroller General ruled that the mark owner's licensing scheme was acceptable, not because of the ownership link, but because the owner actually controlled the manufacturing process of the associated companies and subjected them to rigid quality control procedures. Bowden Wire was distinguished on the ground that Bowden Wire and its subsidiary were independent with regard to production decisions.

In T. Oertli A. G. v. E. J. Bowman (London) Ltd., 1959 R.P.C. 1 (H.L. 1959), a Swiss mark owner was held to have forfeited exclusive rights in its mark by failing to control the manufacturing procedures of its British licensee. The record showed that the mark owner did provide some initial specifications for setting up the production line and did provide some tools for accomplishing this task. See also Baxter Laboratories v. Don Baxter, Inc., 87 U.S.P.Q. 122 (Comm'r 1950), where the Commissioner refused to find a related company relationship under a statutory standard which would support an application for registration despite a record showing joint advertising, exchanges of information, payment of royalties and an original agreement. 
Keebler opinion suggests that the likelihood was quite high that there was no single program of quality control, but rather a multitude of programs. Yet the court refused to look beyond the exercise of actual control by the mark owner in the distant past and the existence of potential control in the relation of the licensor and its licensees to the parent company. ${ }^{57}$

It is reasonably clear that the party challenging a licensing relationship as inadequately controlled should and must produce evidence of inadequate control, or suffer a directed verdict or its equivalent. ${ }^{58}$ It is also reasonably clear that the party challenging a licensing relationship must carry the burden of convincing the trier of fact of the probability that for some significant period the licensor inadequately controlled the quality of its licensee's output. Thus, evidence that the mark owner licensed without a writing or licensed through a writing containing no clauses covering quality standards, even though unrebutted, will not ordinarily entitle ${ }^{59}$ the challenger to a directed verdict on the issue of adequacy of control; nor, indeed, will it guarantee that the trier of fact will infer from such evidence the probability that adequate control was in fact lacking. ${ }^{60}$ When the mark owner introduces some evidence of actual control, it seems that there is no possibility that the party challenging the licensing relationship will be able to get a directed verdict, regardless of the quality of the challenger's evidence that the control exercised was in fact inadequate. ${ }^{\text {B1 }}$

Because no court has yet worked out any guidelines for deciding whether control actually exercised is adequate, cases such as Keebler are almost always resolved in favor of the mark owner on the fact question of adequacy of control. But guidelines for decisions about the adequacy of the licensor's quality control should be developed. The

57 See also Omag Optik Und Mechanik A. G. v. Weinstein, 85 F. Supp. 631 (S.D.N.Y. 1949) (distributor's activities did not affect the firm's ownership of the mark or its post-war right to enjoin its distributor from further making use of it).

58 Sterling Drug Inc. v. Lincoln Laboratories, Inc., 322 F.2d 968 (7th Cir. 1963) (dismissal of plaintiff's action on the ground that it had failed to prove exercise of quality control held erroneous as a matter of law); American Foods, Inc. v. Golden Flake, Inc., 312 F.2d 619, 624 (5th Cir. 1963); E. I. DuPont de Nemours \& Co. v. Celanese Corp., 167 F.2d 484 (C.C.P.A. 1948).

59 But cf. Robinson Co. v. Plastics Research \& Dev. Corp., 264 F. Supp. 852 (W.D. Ark. 1967), discussed at note 42 supra and at notes 79-81 infra and accompanying text.

60 See Geo. A. Hormel \& Co. v. Hereford Heaven Brands, Inc., 341 F.2d 158, 160 (C.C.P.A. 1965). But cf. Ex parte Pure Oil Co., 99 U.S.P.Q. 19 (Comm'r 1953), where an applicant for registration relying on use by related companies was required to document the method and extent of control exercised, with more than a bare recitation that the nature and quality of the services in connection with which the mark is used are controlled by the applicant.

61 Cf. Dawn Donut Co. v. Hart's Food Stores, Inc., 267 F.2d 358 (2d Cir. 1959). 
literature of industrial quality control provides generalized norms ${ }^{62}$ which courts might refine through a series of applications in particular cases. For example, a firm which contracts to buy raw material or a component part ordinarily provides the supplying firm with clear specifications for such things as size, shape, chemical content and tensile strength. If characteristics not easily expressed numerically are specified-finish, color, texture, flexibility-samples of acceptable and unacceptable work are normally provided. ${ }^{63}$ The purchaser generally 'establishes an acceptable quality level-a standard of conformance which enables the supplier to know precisely what deviations from the basic specification will be tolerated. Finally, the purchaser normally advises his supplier what tests will be used at the purchaser's plant to assure that the in-coming product meets the quality specifications.

Sound business practices dictate that a mark owner, as a matter of routine, ought to do as much to control the quality of his licensee's output as a purchaser does to control the quality of his supplier's production. Thus a mark owner should communicate specifications, establish a minimum quality level or conformance standard and assure himself that the licensee's performance conforms to the standard. It seems unlikely that the judicial process can focus meaningfully on the content, as opposed to the existence, of either the basic specifications or the conformance standard, except perhaps when there is mere sham; however, courts can require that licensees actually promulgate specifications and actually use quality control methods of the sort that provide the same level of assurance of conformance to standards which would satisfy a typical, quality conscious industrial purchaser who was purchasing from the licensee.

All that the licensor need do to satisfy the standard is to inspect the licensee's performance by sampling. Whether the licensor's technique measures up to the general standard of what a quality conscious industrial purchaser would do to assure acceptable performance by a supplier will be easily determined, in most cases, by reference to basic principles of statistical quality control. Whether a particular sampling technique permits the licensor to determine if his licensee is performing acceptably is a matter of probability mathematics, ${ }^{64}$ and a court should have no trouble deciding, in a particular case, that there is or is not a probability (law-fact) that the licensor inadequately controlled his licensee's output.

62 Id.; see G. Georgia, The Application of Quality Control to Purchasing-Vendor Relationships, Quality Control in Action 90 (Amer. Mgmt. Assoc. Mgmt. Rep. No. 9, 1958). (1963).

3. Hansen, Qualtty Control: Theory and Applications 3-5, 368, 382

64 Id. at 10. 
Whether tests taken from industrial quality control will prove palatable to courts traditionally reluctant to strip mark owners of rights will depend on the quality of counsels' efforts to educate the courts in the public interest. The burden of persuasion will undoubtedly remain a substantial barrier to those challenging licensing arrangements. However, courts may find that a solicitude for mark owners can be accommodated to the public interest by resort to remedies other than complete extinguishment of mark rights in cases involving uncontrolled trademark licenses.

In the past, courts have been reluctant to strip mark owners of rights, presumably because of the stringency of a decree destroying completely-for all time, for all products, for all places-carefully nurtured mark rights when the mark owner's lapse was momentary and affected only a few consumers. But an all-or-nothing approach to the problem is called for neither by principle nor practice, despite the vogue for the notion that a naked license works a total abandonment of the mark. In practice a naked license does not work a total abandonment of the mark, but a forefeiture ${ }^{65}$ of mark rights only in those product and geographic markets where the mark points to the quality control program of someone other than the licensor. Such a result was reached in E. F. Prichard Co. v. Consumers Brewing Co., ${ }^{66}$ where $A$ was found to have licensed the use of the mark OLDE TOWNE BEER to $B$ north of, and to $C$ south of, the Ohio River. The court found that $A$ had supervised the use of the mark by $C$ but not by $B$, so that the "naked" license to $B$ resulted in an abandonment by $A$ of rights in the mark north of the Ohio. North of the Ohio, OLDE TOWNE BEER was beer controlled by $B$, and south of the Ohio, it was beer controlled by $A$. To permit $A$ to assert a right to control the use of the mark in the north would be to subject consumers there to a possible substaniial change of quality standards, for it would give $A$, who was not controlling quality, power to cut off $B$, who was. There is no basis for divesting $A$ of the mark south of the Ohio, however, for

65 Judge Learned Hand insisted that, in the related field of copyright, it is necessary to distinguish between abandonment, strictly speaking, and what he called forfeiture. He suggested that rights in literary property could be abandoned by some overt act manifesting an intent to surrender all rights in it, but he also said that the law could work a forfeiture of rights in literary property if the public interest required, and the forfeiture would occur despite the absence of an intent to surrender on the part of the proprietor. National Comics Publications Inc. v. Fawcett Publications, Inc., 191 F.2d 594, 597-98 (2d Cir. 1951). Where a trademark owner intends no general surrender or dedication of his mark to the public and where the public interest nevertheless demands a forfeiture, a "property" analysis would suggest that the area in which rights are forfeited be limited to what the public interest demands. In fact, the public interest itself requires that the mark owner be disabled only in markets where the mark points to another, and not in markets where the mark still points to him, for to deny him protection in the latter markets would be to invite opportunists to make confusing uses of the mark.

68136 F.2d 512 (6th Cir.), cert. denied, 321 U.S. 763 (1944). 
there $A$ was controlling quality. ${ }^{67}$ To declare $A$ 's right forfeited there would be to confer upon $C$ (as successor to abandoned mark rights) a power to change quality standards by freeing $C$ from the legal obligation to conform to $A$ 's standards-standards which consumers south of the Ohio had come to expect to govern the production of OLDE TOWNE BEER.

There are several decisions relating to trademark registrations which are consistent with the notion that failure to control a licensee's use of the mark need not disable the mark owner from successfully asserting rights in the mark in all places against all defendants. In Somerlite Ltd. v. Brown, ${ }^{68}$ defendant successfully counterclaimed in an infringement suit for a judgment expunging plaintiff's registration for failing to control the licensee's use of the mark. ${ }^{69} \mathrm{Mr}$. Justice Maugham felt that expungement was proper, since plaintiff's registration covered all of Great Britain and the record showed that in some part of the country, the mark referred to defendant, not plaintiff. But Maugham thought that plaintiff might, after the case, reapply for a registration covering a more limited area, and, on appeal, Lord Hanworth, M.R., agreed that, while expungement was proper, it was still open to plaintiff to apply for a limited registration. The position of Maugham and Hanworth was, in short, that plaintiff, by failing to control his licensee's use of the mark, had not abandoned the mark in all areas or for all products, but had merely forfeited rights in those places where the mark had come to stand for one other than plaintiff.

Courts convinced that a mark owner has failed to control a licensee have occasionally responded by refusing to permit the mark owner to invoke the aid of a court of equity on an unclean hands theory. Such a refusal is probably not the response most consonant with the public interest, but it does hold out to the mark owner the possibility of successfully suing other infringers in other courts in other markets. A refusal by a court to aid a mark owner who has "misused" the mark by failing to control its licensees' uses is, in one sense, then, similar to a judgment that by the failure, rights in the mark have been partially, but not necessarily totally, abandoned.

Broeg v. Duchaine ${ }^{70}$ is the leading licensing-unclean hands case. Plaintiff sought an injunction and damages for infringement of the trademark MOTHER PARKER, which plaintiff had used in the

67 Two other cases which suggest that a naked license has a limited impact on mark rights are Checker Cab Mfg. Corp. v. Green Cab Co., 35 F.2d 631 (6th Cir. 1929); MacMahan Pharmacal Co. v. Denver Chem Mfg. Co., 113 F. 468 (8th Cir. 1901).

6851 R.P.C. 205 (Ct. App. 1934).

69 See also The $88 \phi$ Stores v. Martinez, 227 Ore. 147, 361 P.2d 809 (1961).

70319 Mass. 711, 67 N.E.2d 466 (1946). 
past on biscuit mix in New York; in connection with retail stores in Massachusetts and New Hampshire, and which plaintiff was using at the time of the suit to identify itself as a radio personality on programs discussing food. Defendant was licensed by plaintiff to sell bread under the MOTHER PARKER mark in Southeast Massachusetts, and did so from 1940 to 1943 with appropriate payments of royalty to plaintiff. After 1943, the royalties were unpaid. The court assumed plaintiff to have valid mark rights in MOTHER PARKER for bakery products, but ruled that it could not prevail because it came into equity with unclean hands occasioned by its licensing agreement with defendant, which left defendant at liberty to affix the mark to bread or doughnuts of whatever style or quality he chose. The court suggested that perhaps plaintiff should be denied relief on the ground that the licensing arrangement worked an abandonment of the mark, but, in view of the unclean hands disposition, the court expressly declined to decide the abandonment question.

Presumably the mark MOTHER PARKER meant, in Southeast Massachusetts, bread produced under defendant's control. But what MOTHER PARKER meant to shoppers in New York and New Hampshire and to radio listeners in New England is another question. If bread was in fact still sold under plaintiff's control in New Hampshire, the uncontrolled licensing arrangement in the Massachusetts case should not bar plaintiff against either controlled licensees or against strangers in New Hampshire, assuming New Hampshire and Southeast Massachusetts to be distinct geographic markets. It also seems clear that plaintiff's failure to control defendant's use of the mark, and consequent forfeiture to defendant of the right to control the use of the mark, should not subject plaintiff automatically to the possibility that a second Mother Parker could appear with impunity on a rival radio program (even as a licensee of defendant).

The unclean hands approach to uncontrolled licensing is, then, a mechanism for accommodating the interests of consumers in markets unaffected by the mark owner's dereliction. Its serious defects are that it neither clearly establishes the fact of defendant's ascendency in his own market, nor pinpoints the time when defendant succeeded in part to plaintiff's mark rights.

Of course, a mark owner may be so irresponsible in his dealings with licensees that he forfeits-indeed, abandons-all of his rights to control the use of the mark against all defendants in all product markets and in all places. Everett O. Fisk \& Co. v. Fisk Teachers' Agency ${ }^{71}$ is often cited for the proposition that uncontrolled licensing works a 
loss of all rights in the mark. But the licensor in that case may in fact have forfeited all rights, for the use of its trade name apparently was licensed in all sections of the country to independent local businesses who were permitted to do business as they pleased without the interference or supervision of the licensor. The court said, undoubtedly correctly, that the name stood, not for the efforts, experience and responsibility of the licensor, but for these characteristics of the persons conducting the local offices.

Of course, a licensor could lose all rights in the mark by failing to control only a single licensee. The case of Professor Dr. G. Jaeger v. Jaeger $\mathrm{Co}^{72}$ is illustrative, involving as it did an uncontrolled licensee who served all of England. The court was convinced that the mark JAEGER signaled control by the licensee and not the licensor, holding that the licensor had forfeited to the licensee all rights in the mark in England. In Tanner-Brice Co. $v$. Sims, ${ }^{73}$ Sims agreed to permit Tanner-Brice to develop a grocery chain known as the Sims Service Stores. Later, when Sims severed his relationship with Tanner-Brice, he sought to enjoin further use of SIMS SERVICE STORES. The court ruled that, ${ }^{74}$ by failing to control the use of the name, Sims lost the possible claim that Tanner-Brice's use inured to Sims' benefit. As a result, Sims was left without a basis for claiming mark rights anywhere, even though his "licensee" had not exploited all of the territory of the United States.

Finally, it seems that a mark owner might license the use of a mark to such a great number of licensees, without subsequent exercise of control, that the possibility that the mark could thereafter perform a mark function for anybody-producer or consumer-would be entirely dissipated. U-CONTROL for model airplanes was apparently widely and indiscriminately licensed in such a way that a court concluded that none could thereafter assert mark rights in the phrase. ${ }^{75}$ The terms SILVERBLU, ROYAL PASTEL and TOPAZ for mink pelts were rendered unamenable to trademark status by the practice of a mink farmers' association in offering a license to make an un-

7244 R.P.C. 437 (Ct. App. 1927).

73174 Ga. 13 (Super. Ct. 1931).

74 Orthodoxy has it both that a license, to be valid, must cover an existing mark and that a mark right springs into existence only through a mark use. But see Roessing Bronze Co. v. Concast A. G., 152 U.S.P.Q. 344 (Tm. T. \& A. Bd. 1966) (attaching significance to advertising use). Accepting the initial proposition suggests that a licensing arrangement in which the first mark use is by the licensee is theoretically impossible. In re C. F. Donald Co., 122 U.S.P.Q. 401 (Tm. T. \& A. Bd. 1959), so held. That the Sims case involved a trade name, which attains legal significance only through continued use, rather than a trademark, further complicates Sims' position.

75 American Junior Aircraft Co. v. L. M. Cox Mfg. Co., 46 Trademark Rep. 62 (S.D. Cal. 1955). 
controlled use of the terms to anyone who would pay a stipulated fee. ${ }^{76}$ To summarize, the cases suggest that a mark owner can lose to others all rights in a mark by improperly licensing it to one or to many, or indeed, can be so derelict in controlling licensees as to render the mark useless. While principle suggests that a mark owner should forfeit rights in a mark which is improperly licensed, principle also requires that the extent of the forfeiture be limited by the extent of the dereliction: a mark used in two distinct geographic markets, properly in one and improperly in the other, should be forfeited only in one market; likewise, a mark used in two distinct product markets, properly in one and improperly in the other, should be forfeited only in one market. To punish a mark owner for failing to control his licensee's use in one market by disabling the owner from enforcing mark rights in another unaffected market is unnecessarily detrimental to consumers for whom the mark remains useful in the second market. To assume that occasional harm to consumers in unaffected markets is more than offset by the benefit to consumers in general flowing from the deterrent effects of a total forfeiture rule is to forget that a partial forfeiture rule also deters, perhaps as effectively as the more stringent rule. To suppose that occasional hardship to consumers in "second" markets unaffected by an uncontrolled license is offset by the gains inherent in an easily administered rule ignores the reality that a total forfeiture rule is unlikely to stand the test of hard cases. The courts are likely either to water down the quality control requirement or expand the de minimis category in cases where a few among hundreds of licensees are improperly supervised. ${ }^{77}$ Moreover, such concessions to fairness force the court to draw lines much in the same way as is required by a rule limiting forfeiture to markets where the mark no longer in fact affirms that the licensor controls the quality of the products to which the mark is affixed.

The cases have thus far neither clearly embraced nor clearly rejected the partial forfeiture approach to uncontrolled licensing. While a total abandonment rule has usually been invoked by the few courts which thus far have been confronted with the question of the legal

76 Midwest Fur Producers Ass'n v. Mutation Mink Breeders Ass'n, 127 F. Supp. 217 (W.D. Wis. 1954).

77 In Dawn Donut Co. v. Hart's Food Stores, Inc., 267 F.2d 358, 368 n.6 (2d Cir. 1959), testimony that the mark owner distributed packaging material containing its mark for use by some retail bakeries with which it never had agreements on quality split the court of appeals, 2-1, on the question of the sufficiency of the mark owner's control of its licensees' quality, the majority being unwilling to rule against the mark owner. In Union Tank Car Co. v. Lindsay Soft Water Corp., 257 F. Supp. 510 (D. Neb. 1966), the court stated that the evidence showed that the licensor was not overly zealous in policing its dealers' operations and that the licensor's policing network was far from the most effective possible, but the court could not say that the licensor had forfeited exclusive rights in the mark as a result. 
effect on mark rights of an uncontrolled license, the facts in the cases have supported a conclusion that mark rights in fact had been wholly, rather than partially, forfeited. ${ }^{78}$

In Robinson Co. v. Plastics Research \& Development Corp. ${ }^{78}$ for example, the Robinson Company, a fishing tackle jobber with headquarters in Georgia, licensed the use of its mark to an Arkansas manufacturer of artificial lures. The agreement contained no standards. The court ruled that the naked agreement "effected an abandonment of the mark." The court quoted from Midwest Fur Producers (TOPAZ, SILVERBLU, ROYAL PASTEL) for the proposition that a naked license "amounts to an abandonment of any trademark rights that might otherwise exist in any names so used, and creates an estoppel against the assertion of trademark rights." 80

The estoppel language speaks more to partial forfeiture than to total abandonment, suggesting that as between the parties the licensor has lost the right to exclude the licensee from using the mark in the geographic or product markets covered by the license. The court's formal statement of holding-"The court holds that . . . Robinson Company has abandoned its trademark and lost its exclusive rights thereto . . . ."-is similarly ambiguous, susceptible to both a partial forfeiture (by emphasizing "exclusive") and a total forfeiture (by emphasizing "abandoned") construction.

78 The cases most useful as authority for the proposition that uncontrolled licensing need not lead to total forfeiture are: E. F. Prichard Co. v. Consumers Brewing Co., 136 F.2d 512 (6th Cir. 1943), cert. denied, 321 U.S. 763 (1944) (tarnished by holding that licensee who succeeded in part to licensor's mark rights was estopped by contract to assert full succession, which leaves open interpretation that licensor itself succeeded in part to rights which it earlier lost in full); Checker Cab Mfg. Co. v. Green Cab Co., 35 F.2d 631 (6th Cir. 1931) (tarnished by the absence of any formal licensing arrangement which makes available a concurrent user analysis to explain the case); MacMahan Pharmacal Co. v. Denver Chem. Mfg. Co., 113 F. 468 (8th Cir. 1901) (tarnished by court's analysis of transfer as an invalid assignment rather than an uncontrolled license); and Broeg v. Duchaine, 319 Mass. 711, 67 N.E.2d 466 (1946) (tarnished by court's use of unclean hands analysis).

The cases which announce a broad rule that uncontrolled licensing leads to "abandonment" and which on their facts show conduct amounting to total, rather than partial, forfeiture are: Everett O. Fisk \& Co. v. Fisk Teachers' Agency, 3 F.2d 27 (8th Cir. 1924) ; American Junior Aircraft Co. v. L. M. Cox Mfg. Co., 46 TRADEMARK REP. 62 (S.D. Cal. 1955); Midwest Fur Producers Ass'n v. Mutation Mink Breeders Ass'n, 127 F. Supp. 217 (W.D. Wis. 1954); Tanner-Brice Co. v. Sims, 174 Ga. 13 (Super. Ct. 1931).

The three cases most difficult to reconcile with the proposition that uncontrolled licensing need not lead to total forfeiture are: Robinson Co. v. Plastics Research \& Dev. Corp., 264 F. Supp. 852 (W.D. Ark. 1967); Lea v. New Home Sewing Mach. Co., 139 F. 732 (E.D.N.Y. 1905); Ritz Associates, Inc. v. Ritz-Carlton Co., 35 Misc. 2d 426, 134 U.S.P.Q. 86 (N.Y. Sup. Ct. 1962), aff'd, 138 U.S.P.Q. 404 (App. Div. 1963), aff'd, 141 UU.S.P.Q. 757 (Ct. App. 1964). But they can be reconciled: Robinson Co., by arguing a total forfeiture in fact; Lea, by emphasizing that the case turned on a faulty pleading; and Ritz-Carlton, by emphasizing the importance to the result of the stipulation of no likelihood of confusion.

79264 F. Supp. 852 (W.D. Ark. 1967).

$80 \mathrm{Id}$. at 863. 
The Midwest Fur Producers case is, in addition, a poor precedent to rely on for a rule requiring total forfeiture in all cases, involving, as it did, marks which were expressly held to be generic terms not open to appropriation as marks or names and a "licensing" system so open and uncontrolled as to call for a total forfeiture disposition, even under procedures recognizing the possibility of partial forfeiture. And, as occurs so often, the case misusing the Midwest Fur Producers casethe Robinson Co. case-is itself a poor precedent for a total forfeiture rule, both because the recognition of the putative infringer's defense of forfeiture through an uncontrolled license was preceded by a holding of non-infringement by reason of non-likelihood of confusion, and because the scope of the licensee's uncontrolled use of the mark was apparently at least co-extensive with the area in which the licensor had used the mark..$^{81}$

\section{VI}

Trademark policy countenances trademark licensing provided that a single mark does not designate products or services of different systems of quality control in a single market. Trademark policy requires that insofar as independent firms make use of the same mark at the same time in the same product and geographic market, they behave interdependently in matters of quality control.

At the minimum, a licensee must depend upon the licensor to determine product or service specifications as well as a standard of acceptable conformance to basic specifications. Probably the licensee also must cede to the licensor the right to conduct sampling and inspection operations in the licensee's plant, as well as a power to decide if particular non-conforming items will be marketed under the mark.

While the public interest requires that licensees follow the dictates of the licensor regarding specifications, even greater dependence of licensees upon licensors could be useful to consumers. From a mark conscious consumer's point of view, the more centralized the decision making power regarding the nature or quality of goods or services bearing a particular mark, the better.

81 The mark owner was a jobber with headquarters in Atlanta, Georgia. Probably the mark owner used the mark in an area less than the fifty states. The licensee was a manufacturer who was producing a lure. Id. at 864 . Although the licensee's production and distribution figures are not reported, such information is given for the licensee's chief rival (the defendant in the case), and suggests that the licensee was probably using the mark in all areas of the United States. If these deductions are correct, no area of the country remains which can be said to be unaffected by the licensor's conduct. Since the licensed use involved a fishing lure and since the licensor's mark rights covered the category of fishing tackle and nothing more, no product market remains which can be said to be unaffected by the licensor's conduct. Accordingly, total forfeiture of the licensor's mark rights is an appropriate disposition of the case, and language in the case which suggests that total forfeiture is appropriate regardless of the magnitude and scope of the licensor's dereliction necessarily loses much of its weight. 
Thus, if a group of bedding manufacturers form a company to own and license the use of a mark to members of the group, mattress buyers using the mark as a guide to purchasing decisions would prefer that all mattresses bearing the mark be made of materials from the same sources, be made by laborers having the same skills, be made with the same type of equipment and be identically priced. ${ }^{82}$ Similarly, if a food retailer licenses his mark to other retailers, consumers using the licensor's identifying symbol would undoubtedly prefer that each licensee serve the same foods, of the same quality, in the same quantity and at the same price and, to those ends, use the same kind of equipment and the same methods of preparation. Consumers might find it additionally convenient if each licensee did business in a building identical in design and decor to the buildings of the licensor and the other licensees. ${ }^{83}$

But as independent licensee firms contract away to licensors their autonomy in choosing suppliers, hiring and training employees, buying equipment, selecting customers, disposing of products and choosing methods of selling, pricing and advertising, they begin to transgress upon basic principles of the federal antitrust laws, which are held to be premised on the notion that independent firms must act independently, each firm determining for itself from whom it will buy, what it will produce, at what terms and to whom it will sell.

Trademark policy does not, of course, require licensing. While it might be that the existence of the option of mark licensing assures that consumers are confronted with a few less marks at any time than would be the case if licensing were not a possibility, still it is difficult to assume that any substantial harm would accrue to consumers, from a trademark point of view, if licensing were declared to be unacceptable arrangements under the antitrust laws. Certainly nothing in trademark philosophy undermines an antitrust policy which disables existing competitive units from forming a jointly owned firm to hold and license mark rights to the group, but which permits a licensor to induce new firms to enter the market as franchisees of existing mark rights.

Trademark policy does of course require that if licensing is permitted, a licensing firm control the quality of its licensee's production by setting specifications and performance standards and by sampling the licensee's production at the licensee's place of business. While this articulation of trademark requirements suggests, and indeed the consumer interest requires, that mark owners have to do more in the

82 See United States v. Sealy, Inc., 146 U.S.P.Q. 6 (N.D. Ill. 1964), rev'd, 388 U.S. 350 (1967) ; Denison Mattress Factory v. The Spring Air Co., 308 F.2d 403 (5th Cir. 1962).

${ }_{83}$ See Susser v. Carvel Corp., 332 F.2d 505 (2d Cir. 1964) ; Engbrecht v. Dairy Queen Co., 203 F. Supp. 714 (D. Kan. 1962). 
way of quality control to assure licensee compliance with standards than many trademark lawyers presently counsel, it in no way suggests that mark owners must require that licensees obtain raw materials or equipment from designated sources or market output at designated prices in designated surroundings using designated techniques.

If developing antitrust policy approves of a trademark licensing arrangement requiring a licensee to deal exclusively in designated items, or requiring a licensee to deal with a particular source, or requiring a licensee to buy a particular item, or confining a licensee to a particular territory or location, trademark policy will be neither furthered nor offended; the lawfulness of such restrictions on trademark licensees thus appears to be purely an antitrust matter. 